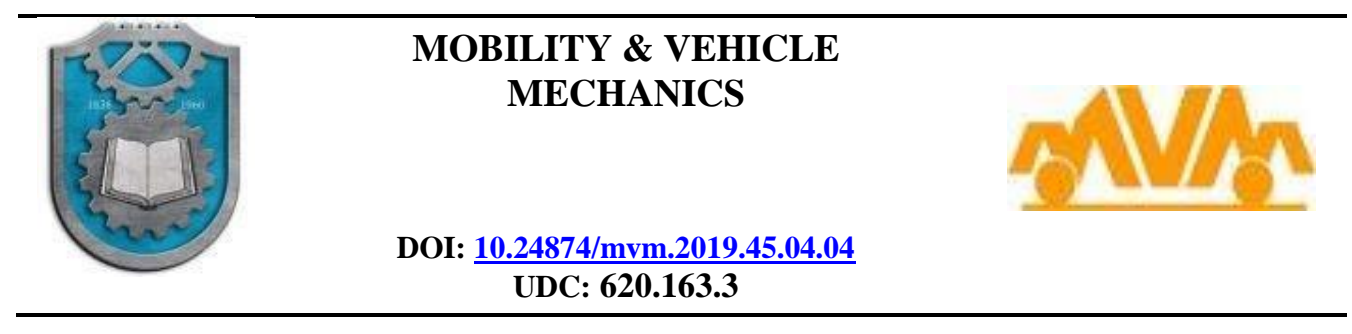

\title{
TURBULENT DEVELOPMENT OF BODY CONCEPTS, MATERIALS AND JOINING PROCESSES IN THE LAST TWO DECADES
}

\author{
Josip Vlahovic ${ }^{1 *}$ \\ Received in August $2018 \quad$ Accepted April 2019 \\ RESEARCH ARTICLE
}

\begin{abstract}
Great changes of the car-body Production concepts in the last few years are the result of a rapid development of the new materials, new Joining processes and a new body-concepts. In the last two decades noticeable are big tendencies/aspirations (we can even say fights) for primacy of aluminum. That made it possible a many of new this competition resulted in development of forming methods and many joining techniques which were developed only for aluminum. They are currently in production of about 30 aluminum-cars. On the other hand, today has the aluminum every day more and more share in the new steel car-body-structures. Following the model of the aluminum structures development, there were also attempts to develop similar technological methods for the steel as well. This attempt was not very successful. The real progress has been made with a development of steel specific technologies. It can be said that the advanced aluminium technologies developed in the 1990s, have forced the rapid development of steel technologies as well primarily new Technologies for steel-sheet. It has resulted that the steel relieved, and will be again a cost-effective car-body technology.
\end{abstract}

KEY WORDS: steel, aluminum, Mg, plastic, carbon

C 2019 Published by University of Kragujevac, Faculty of Engineering

${ }^{1}$ Josip Vlahovic, PhD, Freiberg am Neckar, josip.vl@hovic.de (*Corresponding author)

Mobility \& Vehicle Mechanics, Vol. 45, No. 4, (2019), pp 33-43 


\section{TURBULENTNI RAZVOJ KONCEPATA KAROSERIJA, MATERIJALA I PROCESA SPAJANJA U POSLEDNJE DVE DECENIJE}

REZIME: Velike promene koncepata proizvodnje karoserije automobila u poslednjih nekoliko godina rezultat su velikog napora razvoja novih materijala, novih procesa spajanja i novih koncepata karoserija. U poslednje dve decenije uočljive su velike tendencije (može se reći i borbe) za primat aluminijuma. To je omogućilo da mnogi iz ovog takmičenja razviju metode oblikovanja i mnoge tehnike spajanja koje su razvijene samo za aluminijum. Trenutno se proizvodi 30 modela vozila od aluminijuma. S druge strane, danas aluminijum svakodnevno ima sve veći udeo u novim konstrukcija karoserije od čelika. Prateći model razvoja aluminijumskih konstrukcija, bilo je pokušaja da se razviju slične tehnološke metode i za čelik. Ovaj pokušaj nije bio veoma uspešan. Pravi napredak je postignut razvojem tehnologija specifičnih za čelik. Može se reći da su napredne tehnologije aluminijuma razvijene devedesetih godina prošlog veka naterale na brz razvoj čeličnih tehnologija, kao i pre svega novih tehnologija za čelične limove. To je rezultiralo da se čelik rasteretio, $\mathrm{i}$ to će opet biti isplativa tehnologija karoserije automobila.

KLJUČNE REČI: čelik, aluminijum, Mg, plastika, karbon 


\section{TURBULENT DEVELOPMENT OF BODY CONCEPTS, MATERIALS AND JOINING PROCESSES IN THE LAST TWO DECADES}

\section{Josip Vlahović}

\section{INTRODUCTION}

Development of lightweight bodywork, or to say development of passenger car-body structures, was in the focus of my work within the last 30 years. This can be seen in chart on the Figure 1. Here you can see, at a glance, what happened since the production of the first series aluminum cars in 1903. After a long time of unchanged production of high-volume cars with steel-sheet-metal car-bodies and rare models of aluminum-cars, in 1990s appeared many new technologies, especially for aluminum, which have greatly influenced the way of further development of the carbody- structure. This brought, in the long-standing unchanged steel-sheet-metal production, discomfort and has opened many questions. It caused great changes of the car-body Production concepts. A rapid development of the new materials and new Joining processes has especially supported the rapid development of the production of aluminum cars. It is very interesting that these developments, which went in different conceptual directions, caused big concern for the conventional steel vehicle bodies' manufacturers. It can be said that the advanced aluminum technologies, developed in the 1990s, have forced the further development of steel technologies as well! Following the model of Aluminum development, the steel bodies manufacturers attempted to develop similar hi-tech methods. This has brought no particular progress, because the technical characteristics of the Aluminum and steel are very different. These improvements can be achieved only through development of steel specific technologies. This challenge resulted in development of so many new appropriate Technologies for steel-sheet cars-body. The results was that the steel vehicles production relieved and will be again a cost-effective option for steel-car-body technologies.

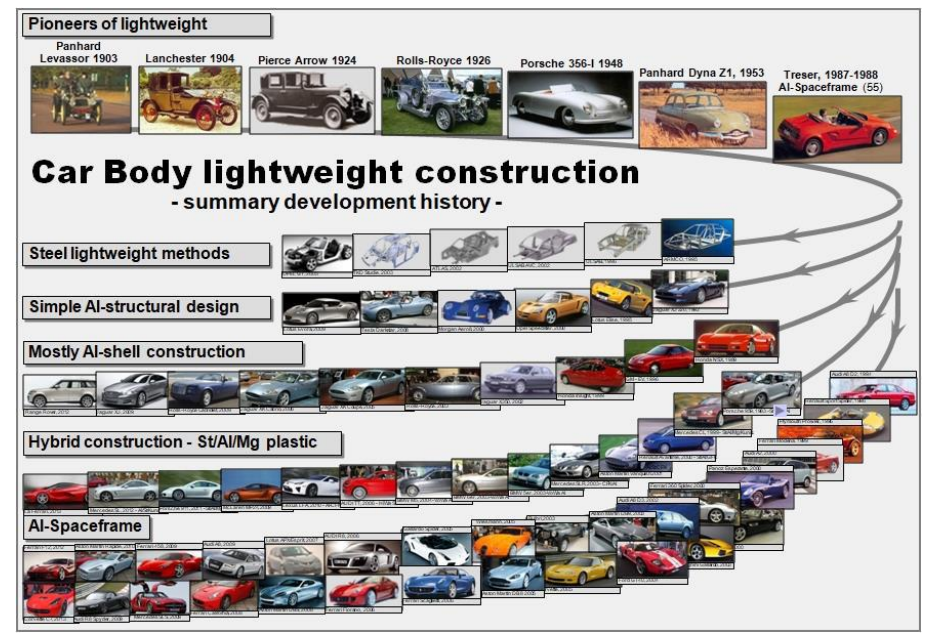

Figure 1. Car Body lightweight history

At the moment, there are in production about 30 Aluminum-cars-bodies. In addition to that the aluminum as a material has every day more and more share in new steel and carbon carbody-structures. It can be said too, there are less and less of the real 100\% "Al cars". The 
Aluminum-cars body-structure get steel parts in critical body areas: A/B-pillar and body side structure. The fact is too, that the aluminum-cars-body are being built more and more in hybrid construction method. It is the fact too, that the so-called ,steel cars", are not all made of $100 \%$ steel anymore. Large number of new steel vehicles, constantly contain more other materials, mainly aluminum, especially in the crash and the spring connection structures. One-material car-body technologies are slowly loosing dominance!

\section{DEVELOPMENT STATUS OF CAR-BODY PRODUCTION - CURRENT STATUS IN THE YEAR 2017}

\subsection{Total car production per year}

Monitoring the production of passenger cars began in the 60's of the last century. In 1969 , for example, 22,752 million vehicles were produced. At that time, the total number of passenger vehicles on the road was about 168.7 million. Ten years later the production has reached about 30 million, until 1999 when the production of passenger vehicles reached the figure of 40 million. In the previous year, this number was over 81 million. Drastic growth has been seen since 2005, when China produced 15.25 million vehicles, and in 2017, China produced as much as 24.8 mio with a tendency of growth. The total number of vehicles running in 2015 totalled 947 million, and today this number exceeds one billion. There are different sources stating that the total number of vehicles vary from 1.069 to 1.2 billion. It is well known that from the beginning of the production of passenger cars between 1886 and 2014 , some 2.552 billion were produced. This means that $28.8 \%$ of them are still on the road.

\subsection{What kind of technology we have used in the past?}

Developer level techniques, the general economic conditions and the expectation of customers were determining the factors of former mass-produced production of passenger vehicles. It was a simple, reliable and profitable production, which can be generally and briefly described as:

- one construction method - steel-sheet construction

- $\quad$ one type of steel - steel-sheet with different wall thicknesses

- two methods of connection - Spot and MAG welding.

However, the new considerably stricter legal regulations, new environmental requirements and new more demanding customer requirements, caused significant changes in the production of passenger cars.

\subsection{What about the current technologies used in car body production today?}

As noted above, today we have one complex production of passenger car bodywork in which various materials and methodes have been applied, which result in lighter, safer and more reliable passenger vehicles. These are the basic features of the modern construction of passenger vehicles-car-body: Use of different Body concepts:

- conventional sheet metal construction

- $\quad$ SpaceFrame (profile, cast, sheet)

- mixed construction: sheet-metal, SpaceFrame, monocoque.

Use of different materials:

- $\quad$ Steel, $\mathrm{Al}, \mathrm{Mg}$, carbon and other plastic. 
Use of different joining technologies:

- different warm and cold joining methods.

\section{DEVELOPMENT OF CAR-BODY PRODUCTION TECHNOLOGIES OVERVIEW}

\subsection{Long time stable car body production}

It can be said that since the beginning of the 50s of the last century, when the production of self-supporting car-body began, the production was stable for almost 60 years with little conceptual and technological changes. It was based on the basic principle of a self supporting bodywork, made of steel sheet alone. It was the only construction method, especially appreciated because it is a very fast, cheap, reliable and profitable method due to the extensive automation. Figure 2 presents the main milestones of technological development of conceptual engineering car-body. These are important technical and technological moments which influenced the entire change in the production of the carbody:

- $\quad$ suddenly many Al-cars in mass production

- $\quad$ space frame new construction method

- new different steel classes

- new different joining technologies

- new steel sheet construction methods.

\subsection{Suddenly many Al-cars in mass production}

Since 1903. until 1987. there was totally 55 different Al-cars in production. Basically, they were small symbolic series until 1953 when Panhard Dyna Z1 in total production from 1953 to 1956 produced 39,460 exemplars. Then there was a small break in the production and development of Al-cars, until 1987. That year, appeared Treser a new unusual Al-car, which was not only in aluminium, but also applied a new concept of bodybuilding. It was the first that implemented the Space Frame concept in a very small series. All that remained without much of attention until 1984, when the mass production of the Audi A8 began, that also implemented the Space Frame concept (Figure 3 and Figure 4). It was the first sign that something new was happening in the car-body production. From 1984 to 2000, 11 Al-cars came into the series. It was only one of the emerging signals for steel car manufacturers that they also have to change something in the long-standing "Long Time stable car body production". 


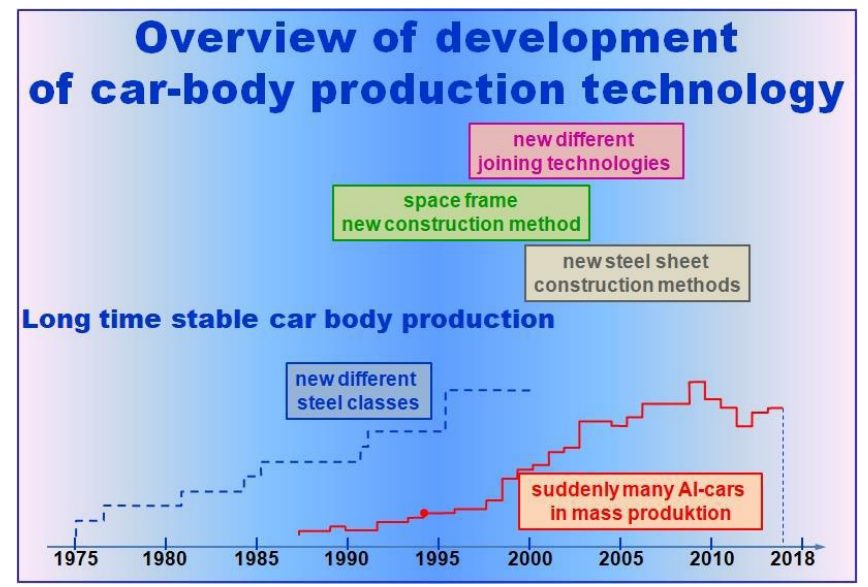

Figure 2. Development of car-body production technologies overview

\subsection{Space frame as new car body construction method}

With the Audi A8, began mass deployment of this new concept of construction of car bodys. About this concept given in the 90s a lot of talking, researching and experimenting occured. This Al-car-body construction concept is simply described by the following definition: „Space Frame supporting structures are thin-walled spatial structure, whose elements (straight, 2D or 3D curved) have closed sections and in which the nodes of the elements consistently spatially interconnected" [3]. It is clear that this principle of car-body design has "lightweight" as a leitmotif and as a result of years of work on this topic the following definition was created: „, Lightweight design is a balanced synergy between shape and mass in the available space“" [3]. Today, after almost a quarter of a century of applying this principle, there are visible changes and can be said that slowly the Space Frame car-body concept further developed in the direction of "Multi material" design.

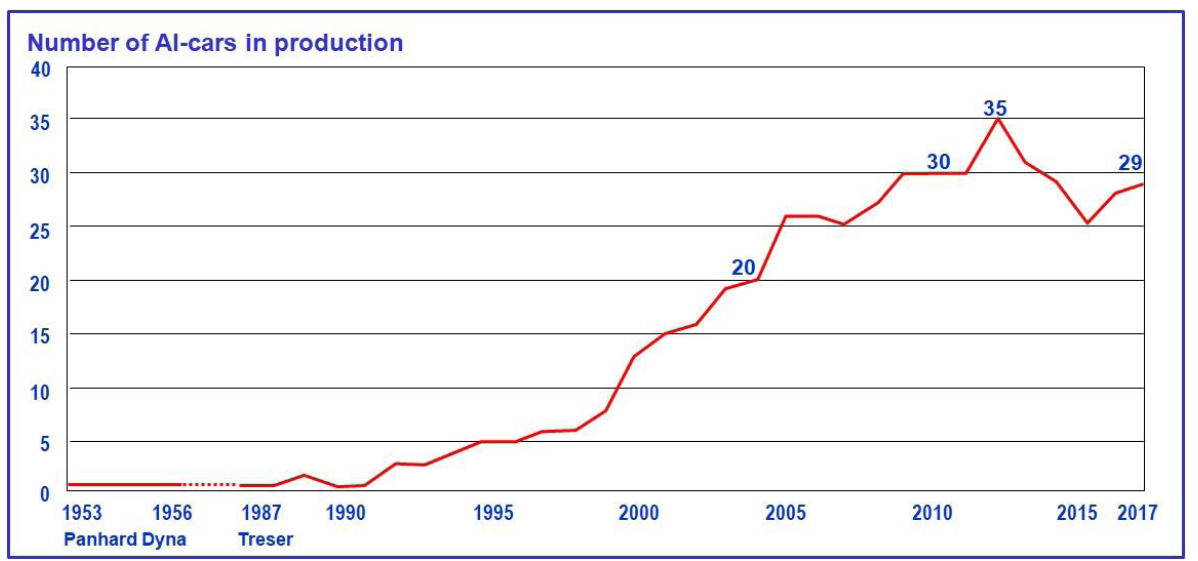

Figure 3. Number of Al-cars in production 


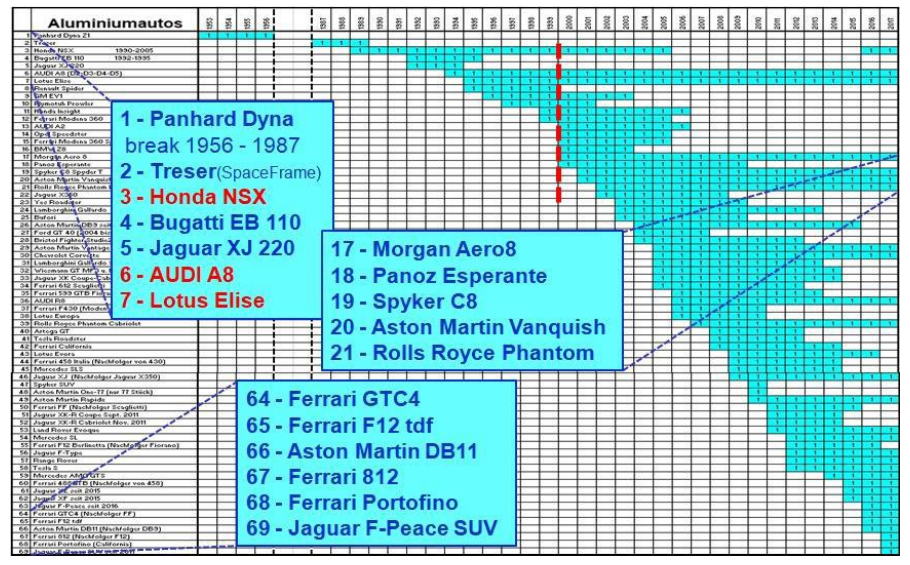

Figure 4. Aluminum cars in production 1953 - 2017

\subsection{New different steel classes}

It is clear that after major changes in the development of the concept of car-body construction and application of Aluminum as a big competitor to steel, there was a need to make improvements in the quality and the types of steel used as well as in the field of construction method of car-body with steel. So, in the 1990's many new types of steel have been developed, improved both in strength and in the way of forming process.

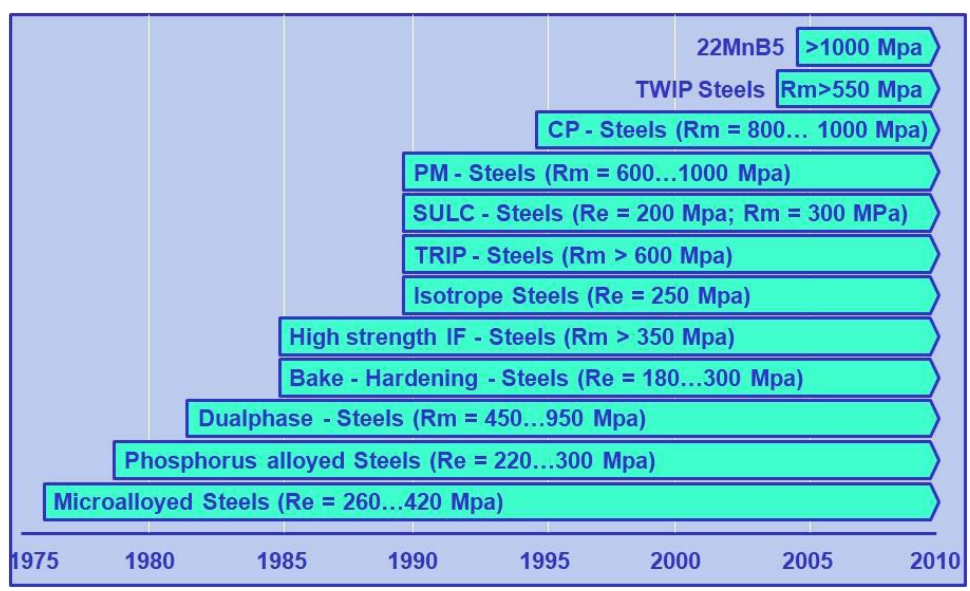

Figure 5. Development of High Strength Steels since 1975 [9]

\subsection{New different joining technologies}

In the 90's, the development of new "joining" technologies began to appear, especially the so-called "Cold joining methods". Until then, dominating methods were "warm joining" as "spot welding", which were used in the serial production of car-bodies since the 30's of the last century. At that time the self-supporting bodywork method was patented, based on "steel-sheet" components, as the only profitable, fast and cheap method. Everything started 
with the development of the basic "Self-piercing riveting" technologies for Aluminum. Today there are two types of this technology: "Semi-hollow and Grip Self-piercing riveting". In order to increase the effect of Selfpiercing riveting, since it is like the "Spot welding" method that results in "Discontinuous body structure", new "Structural adhesive" methods has begun to intensify. So today we have great application of "Self-piercing riveting", but with pre-glued "connecting flange". This results in a "Continuous body structure" which means that all "structural parts" have a full length "closed cross sections". Such approach results in a body-structure with much greater "torsional stiffness". This means that the body structure is much more stable, less vibrating, and ultimately considerably lighter than the body-structure that does not have an adhesive "connecting flange". At the same time, other "cold joining methods", the so-called " Different "Clinch spots" methods, which are used as auxiliary methods, to position the parts before, for example at "Structural adhesive" or before "Roller connection". This method also allows the glued parts to hold and tighten and prevent interference and movement of parts and vibrations. Interestingly, the old simple "warm joining methods", the so-called "Resisting spot welding" for the traditional principle of "steel / alu-sheet" body construction are improving as well. The same situation is with already known methods for steel and aluminum joining, such as MIG, MAG and different Laser welding. Other "cold joining methods" have also been developed, for example: Friction stir welding FSW (cold), Flow drills screws, Tack impact, etc.

\subsection{New steel sheet construction methods}

In the late 90's of the last century many new steel-sheet construction optimization methods have been developed and perfected so that they can achieve the efficiency of new AlSpaceFrame constructions. These methods enable "steel-sheet construction" to be significantly stiffer and and lighter and thus remain the dominant "body construction" method. A brief overview of these new methods is shown in Figures 6 and 7. All these methods are based on two simple principles: Tailored \& Patch of sheet metal parts.

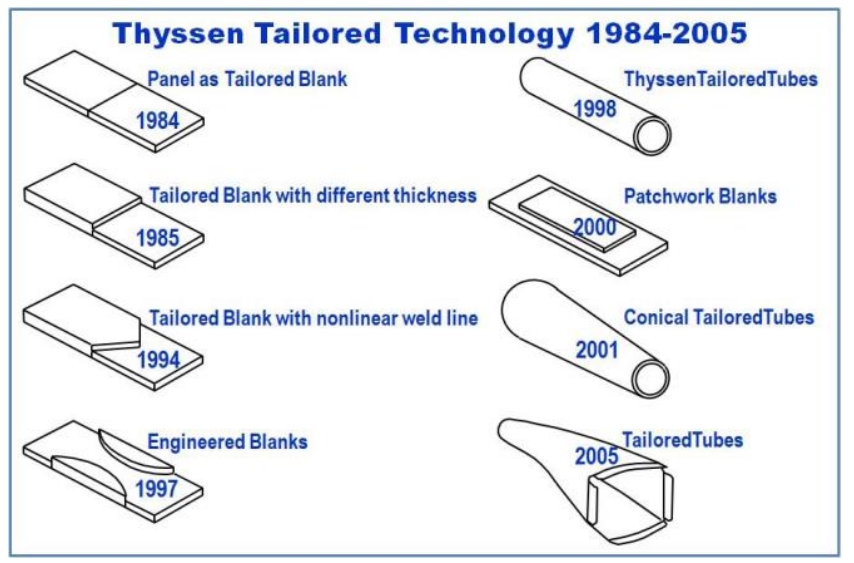

Figure 6. New steel-sheet construction methods - Tailored Blanks [10] 


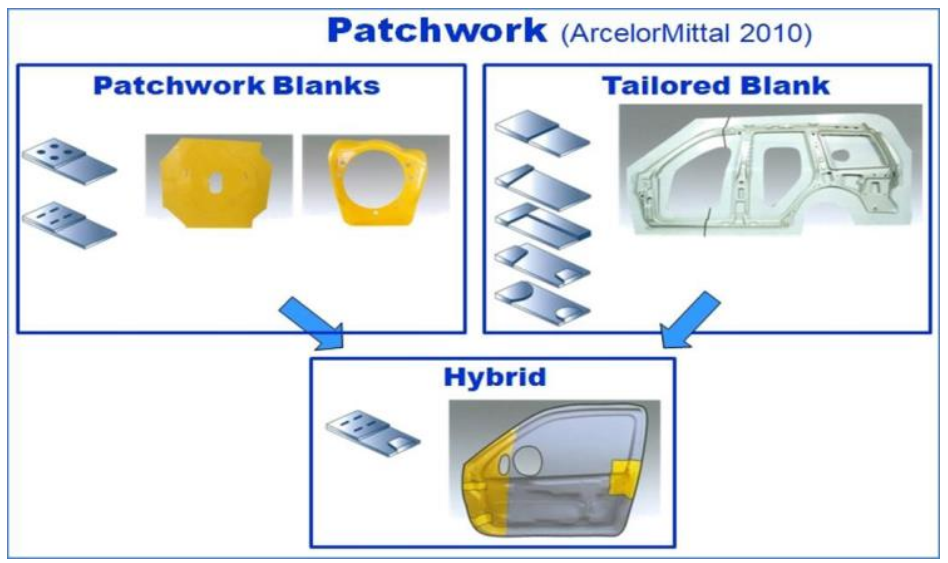

Figure 7. New steel-sheet construction methods - Patchwork [11]

\section{COMPARISON OF DIFFERENT MATERIALS AND JOINING TECHNOLOGIES}

This is a theme that 30 years ago did not exist, because we have used only "one material and one technology". Today's situation provides a lot more creative possibilities for car-body design and that is why, this rendering as information is very useful (Figure 8).

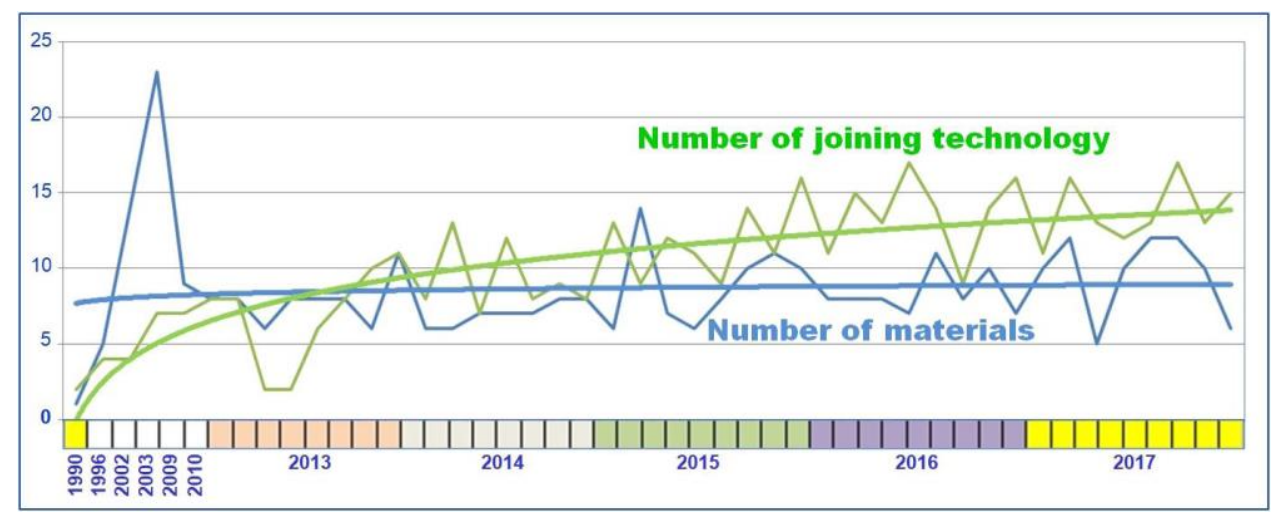

Figure 8. Comparison of number of different materials and joining technologies

If we look in the diagram, we can see significant oscillations on the left part (1996-2013) in the number of applied materials and joining technologies. These oscillations are understandable in the process of searching for the optimum.

It is evident that this number of applied materials, as well as the number of applied joining technologies, have stabilized over time. Talking about an average numbers, one could say that width a new modern car-body (forerunner) there are about 14 different materials and 9 different joining technologies. 


\section{CONCLUSION - NEW VIEWPOINTS FOR THE FUTURE}

All the facts indicate that the times when cars were made from a single steel sheet of various thicknesses have gone, meaning a single material and a single technology is a matter of the past. Neither the method of a single material, introduced with Aluminum, lasted for long. So, the all attempts to produce future cars in new technologies, but from only one material, belong to the past. The data has already shown that we do not have pure "Al-body" today, as well as all the less pure "St-body "except in large-scale daily car manufacturing.

It is clear that new directions are being introduced and that they can be summarized to the following conclusions:

- Most car bodies will still remain made of steel as basic material, but with the introduction of modern processing technology and new materials

- Medium and high class as well as premium cars will have in principle hybrid construction (As today already partially exists) with a basic structure of steel or aluminum, with implementation of other materials and made by introducing modern technologies.

- Exotic sports cars still have the basic structure (as it is to date) from carbon with the addition of other materials and manufacturing technology.

\section{REFERENCES}

[1] Jahreskatalog der AUTOMOBIL REVUE, HALLWAG Verlag, Bern CH, von 1968 bis 2015.

[2] Enzyklopädie des Automobils, Weltbild Verlag GmbH Augsburg, Orbis Publishing Ltd, London, 1990.

[3] Vlahovic, J.: "Gestaltung von T-förmigen Knotenpunkten in dünnwandigen Rahmentragwerken”, Dissertation, RWTH Aachen, 2004, ISBN 3-8322-4033-0.

[4] TRESER, Manufacturer brochures, 1990.

[5] Mayer, H., Audi AG: "Das Karosseriekonzept des neuen A8", International Circle of Experts on Carbody Construction, 7/8 Nov., Bad Nauheim, 2002.

[6] Koglin, K., Audi AG: "Neue Fertigungstechnologien für die A8-Karosserie", International Circle of Experts on Carbody Construction, 7/8 Nov., Bad Nauheim, 2002.

[7] Dullinger, M., Kempinger, K.: Der fünfte 5er, "Internationaler RohbauExpertenkreis", BMW AG - Dingolfing, 22.07.2003.

[8] Dullinger, M., Kempinger, K., Der fünfte 5er: "Internationaler RohbauExpertenkreis", BMW AG - Dingolfing, 22.07.2003.

[9] Bernhard, C.: "Vortrag an der HTL Waidhofen", Department für Metallurgie Montanuniversität Leoben (A), 22.Feb. 2008.

[10] Adam.: „ThyssenKruppDrauz, Evolution from first Tailored Blank to near net shape“, Thyssen Tailored Tube, Wolfsburg 26-27 Mai 2009.

[11] ArcelorMittal Patchwork, Euro Car Body, Bad Nauheim, Oct. 2010.

[12] Aston, M.: „The new Rapide Ian Minards, Andrew Syvret Aston Martin Lagonda“, Ltd., GB, Euro Car Body 19-21 October 2010.

[13] Manabu, O., Atsushi, M., Hideo, S.: „Euro Car Body“, Global Car Body Benchmarking Conference, 2010.

[14] Atsushi, M., Manabu, O., Hideo, S.:" Lexus the new LFA“, Toyota Motor Corporation, JP, Euro Car Body, 19-21 October 2010. 
[15] Andreas, F., Jürgen, B.: „Audi-The new A8, Euro Car Body“, 12th Int. Car Body Benchmark Conference, Bad Nauheim, 19/21 Oct. 2010.

[16] Manabu, O., Atsushi, M., Hideo, S..: „Euro Car Body“, Global Car Body Benchmarking Conference, 2010.

[17] BENTELER Automotive: „Technologies \& Products of PG Structures“, Euro Car Body, Bad Nauheim, 2012.

[18] Variform, F.: „Official technical brochures“, 14th Global Euro Car Body Award, Bad Nauheim, Oct. 2012.

[19] Günther, A., Michael, T., Daimler, A.G.: „Euro CarBody“, Global Car Body Benchmarking Conference, 2012.

[20] Lloyd, R., Movce, G., Black, S., Rickards, M.: „,The all new Range Rover L405“, JLR, GB, Euro Car Body, 18. Oktober 2012.

[21] ThyssenKrupp, Tailored Strips - Brochures, 14th Global „Euro Car Body“ Award Bad Nauheim, Oct. 2012.

[22] Günther, A., Michael, T., Daimler, A.G.: „The new Mercedes-Benz SL“, 14th Global EuroCarBody Award, Bad Nauheim, Oct. 2012.

[23] Lloyd, R., Movce, G., Black, S., Rickards M.: JLR, GB, „The all new Range Rover L405“, EuroCarBody, 18. Oktober 2012.

[24] Shawn, T., Jared, C.: „Honda, Euro CarBody“, 18th Global Car Body Benchmarking Conference, 2016.

[25] Petr, Š., Jiří, N.: „Euro Car Body“, 18th Global Car Body Benchmarking Conference, 2016.

Tim, H., Dominik, H.: „The newAudi A8“, AUDI, Euro Car Body, Bad Nauheim, 2017. 